\begin{tabular}{|c|c|}
\hline 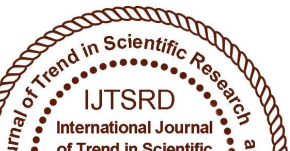 & $\begin{array}{l}\text { International Journal of Trend in Scientific } \\
\text { Research and Development (IJTSRD) }\end{array}$ \\
\hline $\begin{array}{lll} & \\
0\end{array}$ & International Open Access Journal \\
\hline 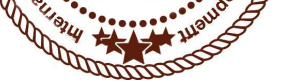 & ISSN No: $2456-6470 \mid$ www.ijtsrd.com | Volume - 2 | Issue -5 \\
\hline
\end{tabular}

\title{
Critical Anaylsis on the Effects of Triple Talaq, the Plight of Women, its Impact on the Society Muslim Community
}

\author{
Simran Chhallani \\ B.B.A., L.L.B., Indore Institute of Law, \\ Indore, Madhya Pradesh, India
}

\section{ABSTRACT}

Today, the issues of women rights in muslim personal law is highly controversial. Specially, muslim women rights relating to triple talaq, inheritance, maintenance has got much attention nowadays. A muslim man can divorce his wife by prouncing three times talaq. When husband clearly mentions it is called as express talaq. After that husband and wife cannot be together back until wife marries someone else. The legal decisions are based on the norms mentioned in quaran therefore, certain anomalies need to be eradicated by giving true essence of holy quaran for the benefit of muslim women's right. There is three types of talaq namely, unlike other religion marriage is viewed as sacrament but, under, muslim law it is civil and social contract. Talaq-ul-sunnat sanctioned by prophet is sub-divided into : Talaq-e-ehsan, Talaq hasan, Talaq-e-biddat. The current debate on triple talaq, centred on the Sharaya Bano and several other petitions which considers no aspect of Islamic personal laws which amounts to violate the spirit of constitution. The whole triple talaq has become a battleground for the culture vs social debate. In this paper the author deals with the question of triple talaq in the light of the recent petition filed in the Supreme Court for declaring such talaq invalid. The author argues that there is an already existing legal precedent established by the apex court with respect triple talaq which should be followed instead of resorting in aggressive approach which may become dominant to muslim women themselves. This research paper analyze to attempt the on-going implications on triple talaq, muslim personal law and solutions to empower muslim women.

\section{INTRODUCTION}

The Personal law in India is a law for people of different religion and applicable to the religion of the

person. For many decades Muslim women are fighting for gender equality in Islamic law that govern right related to marriage, divorce and property rights. However All- India Muslim Personal Law Board is one of the influential body in Muslim community. Many times this body rejected the proposal to change the Muslim Personal Law as they believe it will infringe their basic principles of Islam. After the 1986 Shah Bano Case, the enactment of Muslim Women (protection of Rights and Divorce ) Act. And also the quaran had no provision for talaq of this kind. You cannot give talaq in one sitting. It has to be over a period of three months or two menstrual cycles. And only when the couple cannot reconcile in the intervening period that the talalq becomes valid after the third and final pronouncement. Also, if the women is pregnant at that time then also the talaq is void.

\section{Origin of triple talaq}

Then why is the instant triple talaq, a common occurrence among the Muslims in India? "There was no provision for instant talaq in the Quaran. But later when Sharia laws began to be codified and four schools of jurisprudence emerged, Imam Hanifa, whose school of thought is followed in India, gave the talaq his seal of approval.

\section{MEANING OF TALAQ}

Talaq in its original sense means repudiation or rejection but under Muslim law, it means a release 
from the marriage tie, immediately or eventually. Muslim husband who may repudiate his wife at his own pleasure with or without cause. He can pronounce the talaq at any time. It is necessary for him to obtain the prior approval of his wife for the dissolution of his marriage. One view is that if the husband was forcibly made drunk, and has pronounced talaq, such a talaq will not take effect. A talaq pronounced by a person, in a state of intoxication or by one laboring under a temporary stupor fromm the use of some practice, or any other cause is invalid. Any Sunnni Mohammedan of sound mind who has attained the age of majority may divorce his wife whenever he likes by pronouncing talaq without assigning any cause. The husband may give talaq by mere words without any talaqnama that is Oral talaq. A talalq maybe in writing that is called talaqnama.

Effects of triple talaq on Muslim women:

Imagine living with the mental insecurity that years of your marital alliance can be ended just by utterance of three words. The recent practices of talaq being uttered thrice over telephone, e-mail or letters and text messages. This innovative mode of divorce is widespread use by the Muslim men without giving any plausible explaination to the wives. As a result divorced wives are left destitute. The miserable plight of Muslim women are discriminated and shunned by caprices of personal laws. The struggle a Muslim women has to face in order to claim maintenance after divorce especially after the enactment of the Muslim Women's Act 1986. The number of impoverished Muslim women has risen as a result of a rise in oral divorces in recent times. Many muslim women are uneducated and cannot provide for themselves, thus triple talaq only serves to magnify their hardship. Living as divorced women in a highly patriarchial and judgemental society like India is very difficult. While it is important to respect the religious and cultural minorities in diverse and secular country like India, it is also critical to ensure that such practices do not abuse basic human rights. Triple talaq diminishes the ability of Indian Muslim Women to live with dignity. Such practices instills fear and anxiety in minds of countless Muslim women. Since, triple talaq has been abolished in 22 Muslim majority countries, it is difficult to see the need to hold on to it. Effective reforms are necessary and much awaited in the territory of Muslim personal law.
What is Instant Triple Talaq Bill: The Muslim Women(Protection of Rights on Marriage) bill,2017?

The Supreme court has already declared this instant talaq, as unconstitutional on August 22, 2017(Shayara Bano vs Union of India) this bill is considered to be historical verdict of Supreme court by making it a punishable offence. It makes the pronouncement of "talaq-e-biddat" void and illegal. According to clause 3of the bill," any pronouncement of talaq by aperson upon his wife, by words, either spoken or written or in any electronic form shall be void and illegal". In August, this year the Supreme Court had found the practice of muslim male divorcing his wife by pronouncing talaq three times, to be illegal and unIslamic. The bill is to protect the rights of married women and to prohibit divorce by pronouncing talaq by their husbands. This Act shall come into force on such date as the Central Government may, by notification in the official gazette. Titled, the Muslim Women (Protection of Rights on Marriage) 2017, it reportedly makes instant triple talaq, a cognizable and non- bailable offence, punishable with imprisonment for three years. The law is about justice and respect for women and is not about any religion or community. The proposed law would only be applicable on instant triple talaq and give power to the victim to approach a magistrate seeking allowance fo herself and minor children and she retains the custody of minor children. And this is the most ambiguous part of the bill, upon which the government was questioned by opposition in the parliament. ${ }^{1}$

\section{Should triple talaq be abolished?}

Traces of triple talaq can be found dated back to 1932 in Indian Judiciary from Anisa Khatun's Case. Finally after great struggle, with the advent of Shayara bano's PIL with 5 other women. "The Supreme Court bench of five after going through a 397 paged ruling, declared triple talaq as unconstitutional with $3: 2$ majority. A study of 2011 census reveals that for every divorced Muslim women, which depicts the backwardness and discrimination against muslim women. "Given that triple talaq was realized to be unjust and discriminatory against women, many countries including major muslim countries like Pakistan, Iran, Jordan, UAE, Turkey, Egypt, etc have already banned this unilateral form of divorce. The banning of triple talaq turned out to be so difficult and 
controversial in India due to two reasons, firstly, the muslim personal law. It made the Shariat board as functional law board for muslim's personal matters and prevents state interference. Secondly the article 25 of the Indian constitution gives each the right to freely practice their religion, which empowers the personal board and exempts them from falling under uniform civil code. However article 14 is significant is balancing the act, making a good case for judicial activism.

What will be the impact of triple talaq bill in India?

The bill which is made to ensure justice to women, ridding them of the unilateral divorce, seems to be getting politicized both by government and opposition. Whatever might be the political agenda, the fact that triple talaq bill as a whole remains as a great success to the secular India pacing way for a uniform civil code free from patriarchial, orthodoxly and superstitious beliefs and practices. However, no law, unless internalized by society can work successfully, as is evident by cases like dowry-deaths, caste practices, for which many laws re formulated, yet the desired result is far from materializing. The triple talaq bill, though a small but historical step, is a welcome move towards gender justice in country.

What are the kinds of talaq under Muslim law in India?

\section{Talaq-ul- Sunnat}

It may be further sub-divided into : Talaq ahsan, Talaq hasan.

\section{Talaq-ul-Bidaat}

\section{Talaq-ul}

Sunnat is regarded to be approved form of talaq. It is based on prophet's tradition.

\section{Talaq Ahsan}

This is the most proper form of repudiation of marriage. To be in ahsan form, the proceedings of divorce must satisfy certain conditions. These conditions are as follows:-

$>$ The husband must pronounce the formula of divorce in a single sentence.

$>$ The pronouncement of divorce must be in a state of purity;

$>$ He must abstain from intercourse for the period of idaat. Single pronouncement of the civil words of talaq and sufficient opportunity to the spouses for reconciliation, are the two reasons for calling this form as the most "proper' form of talaq.
Talaq Hasan - This talaq is also regarded to be the proper and approved form of talaq.In this form too, there is a provision for revocation. The formalities required under this form are as under:-

$>\quad$ The husband has to make single declaration of talaq in a period of "Tuhr".

$>\quad$ In the next tuhr there is another single pronouncement for the second time.

The first and second pronouncements may be revoked by the husband. If he does so, either expressly or by resuming conjugal relations, the word of talaq become ineffective as if no talaq was made at all.

But, if no revocation is made after the first and second declaration then lastly the husband is to make third period of purity. As soon as the third declaration is made, the talaq becomes irrevocable dissolves and the wife has to observe the required iddat.

\section{Talaq-ul-biddat}

The talaq-ul-biddat has its origin in the second century of the Islamic-era. According to Islamic scholar this mode of talaq was introduced by the omayad kings.

It is a disapproved mode of divorce. A peculiar feature of this talaq is that it becomes effective as soon as the words are pronounced and there is no possibility of reconciliation between the parties. ${ }^{2}$

\section{Judicial trends: The case of Shayara Bano}

The current debate on triple talaq is centred on the Sharaya Bano and several batches of petitions as well as Supreme Court own suo moto PIL to consider whether certain aspects of Islamic personal laws amount to gender discrimination and hence violates the constitution. The petition hence challenged the validity on triple talaq on the touchstone of article 14, article 15 , article 21 , article 25 of the constitution. It states: it is submitted that religious officers and priests like imams, maulvis, etc. who propagate, support the practices like talaq-e-bidat, nikaha halala, and polygamy are grossly misusing their position, influence and power to subject muslim women which treats them as chattel, thereby violating their fundamental rights enshrined in article 14,15,21,25 of the constitution.

\footnotetext{
${ }^{2}$ www.shareyouressays.com

www.dnaindia.com
} 
The best example of confrontational politics leading to actual victimization of the woman in question was the Shah Bano Case. The case pertained to maintenance to the muslim wife after talaq had been pronounced. Shayara bano, a 35-year old woman, from the state of Uttarakhand, filed a petition in the Supreme Court, asking for talaq to be declared unconstitutional. Her husband, a real estate agent named Rizwan Ahmed,had divorced her by talaq the previous year. Her petition attracted other parties and groups that have been demanding a ban on the talaq practice. $^{3}$

\section{Conclusion}

Nikah as described in the holy quaran is sacred bond between man and women and last for the remaining part of their lives. Before enforcing divorce the couple is required to stay separately to feel the pain of Zudai under the monitoring of Qazi. Divorce is the last undesirable step in the Quaran when all the effort $s$ for unification go in vein after long presence. Neverthless, the custom of triple talaq by a husband to divorce his wife, though not sanctioned in quaran, has been vogue since th enactment of Muslim Personal law Act in India.Whatever, the fact may be muslim men are taking advantage of unlimited freedom of power in terminating marriage through triple talaq. Although, some efforts were made to eradicate triple talaq in India. It is therefore suggested that the right course is to go back to Quaran and sunnah ans seek guidance from them. Divorce to be legal and effective must strictly follow the rules of Shariah. Any other form of divorce which is in conflict with quaran must be declared a crime. The modern legislation existed in Africa and Asia, under which no marriage could be dissolved without the intervention of court. But it is realistic enough to take recourse to law where persuation fails to save the pious purpose.

\section{REFERENCES}

1. Prof I.A. Khan, MOHAMMEDAN LAW

2. All India Muslim Personal Board

3. Muslim Women( Protection of Rights On Marriage) Bill,2017

4. Shayara Bano vs Union Of India And Others

5. http://www.shareyouressays.com/knowledge/what -are-the-kinds-of-talaq-under-muslim-law-inindia/117523

6. Pragti Ghosh, What are the kinds of talaq under muslim law in India?

\footnotetext{
${ }^{3}$ http://ili.ac.in/pdf/paper517.pdf
} 